\title{
Health Education to Stop Open Defecation and Use of Healthy Latrines as an Effort to Increase Knowledge in the Community of Rt 003 Pemurus Village
}

\author{
Meitria Syahadatina Noor * \\ Faculty of Medicine, \\ Lambung Mangkurat University, \\ Banjarbaru, Indonesia \\ Gabrielle Nida Tarlianty \\ Faculty of Medicine, \\ Lambung Mangkurat University, \\ Banjarbaru, Indonesia
}

\author{
Rahmat Hidayat \\ Faculty of Medicine, \\ Lambung Mangkurat University, \\ Banjarbaru, Indonesia \\ Oktavianti Cahya Ningrum \\ Faculty of Medicine, \\ Lambung Mangkurat University, \\ Banjarbaru, Indonesia
}

\begin{abstract}
The purpose of the PBL 2 intervention activity is to increase knowledge and awareness of the community in Pemurus Village RT 003, Aluh-Aluh District regarding healthy latrines, make appropriate septic tanks, and change people's behavior about healthy lifestyles. The PBL 2 intervention method was carried out boldly through WhatsApp. In addition to the intervention, pre and post-test were given via google forms. The test results showed a Sig value of $0.031(<0.05)$, meaning that there was a significant difference between the knowledge of the community at the time of filling out the questionnaire before and before the intervention, namely increasing knowledge of the Pemurus Village community RT.003 about healthy latrines. Those involved in this activity are 15 Pemurus Village communities RT 003 who are available to participate in the activity and contact WhatsApp and follow the activities that will be carried out. In addition, the village head, village officials, and community leaders in Pemurus Village were also involved in the intervention activities. The community in RT 003 Pemurus Village is expected to play an active role in personal and public health efforts, especially related to the use of healthy latrines so that later they can create better health degrees. With the increase in knowledge through this study in the community, it is hoped that it can be a trigger for the community to be able to apply defecation behavior using healthy latrines.
\end{abstract}

Keywords: Open defecation, healthy latrines, PBL, RT 003 Pemurus Village

Received: 02 October 2020; Accepted: 13 December 2020; Published: 24 March 2021

\section{INTRODUCTION}

A public health problem that is still a global problem is open defecation. Open defecation is an example of unhealthy behavior. Open defecation is an act of disposing of feces or feces in fields, forests, bushes, rivers, beaches, or other open areas and allowing them to spread to contaminate the environment, soil, air, and water [1].
World Health Organization data (WHO) in 2020 stated that Indonesia is the second-largest country in the world whose population is still practicing open defecation. This situation causes about 150,000 Indonesian children to die every year due to diarrhea and other diseases caused by poor sanitation. The latest data from the CommunityBased Total Sanitation (CBTS) monitoring site published

\footnotetext{
${ }^{*}$ Correspondence concerning this article should be addressed to Meitria Syahadatina Noor, Faculty of Medicine, Lambung Mangkurat University, Banjarbaru. E-mail: drmeitria@yahoo.com

(C) 2021 The Author(s). Published by KKG Publications. This is an Open Access article distributed under a Creative Commons AttributionNonCommercial-NoDerivatives 4.0 International License.
} 
on the Indonesian Ministry of Health's website shows that there are still 8.6 million households whose family members are still practicing open defecation as of January 2020 [2].

Health problems in Indonesia are still characterized by high rates of morbidity and mortality due to environmental-based diseases. Diseases whose transmission is related to water and the environment is an unfinished health problem. Based on WHO data, deaths caused by waterborne disease reach $3,400,000$ people per year. Of all these deaths the cause is rooted in poor sanitation and water quality [3]. According to the 2013, Basic Health Research (Riskesdas) data on the proportion of households based on the use of defecation facilities, the national average for defecation behavior in latrines is $(82.6 \%)$. Five Provinces with the highest percentage of households that behave properly in defecation include DKI Jakarta (98.9\%), DI Yogyakarta (94.2\%), Riau Islands (93.7\%), East Kalimantan (93.7\%) and Bali $(91.1 \%)$. While the five lowest provinces are West Sumatra (29.0\%), Papua (29.5\%), South Kalimantan (32.3\%), North Sumatra (32.9\%) and Aceh (33.6\%) [4].

According to regional qualifications, based on the results of Riskesdas 2013, access to proper sanitation facilities reached $72.5 \%$ in urban areas and $46.9 \%$ in rural areas. Meanwhile, based on the place of final disposal of feces, $66 \%$ of households in Indonesia use a septic tank as a place for final disposal of feces. Households using the Waste Final Disposal Channel (SPAL) are 4\%, ponds/rice fields are $4.4 \%$, rivers/lakes/sea are $13.9 \%$, hole 4 soil is $8.6 \%$, beach/field/ gardens by $2.7 \%$ [4].

According to data from the Health Profile of Banjar Regency in 2017, the population with access to proper sanitation facilities (healthy latrines) only reached $63.8 \%$ while the target of $100 \%$ of the population must have access to proper sanitation. The lowest access to proper sanitation is in Paramasan District (4.5\%), while the highest access to proper sanitation is in Kertak Hanyar District (95.2\%). Meanwhile, Aluh-Aluh sub-district is in the fourth lowest position with a percentage of $12 \%$. The low access to proper sanitation in Banjar district is related to tradition and the availability of clean water. There are still many traditions or habits of open defecation (BABS) in rivers and gardens. Pemurus Village is administratively included in the Aluh-Aluh District, Banjar Regency, South Kalimantan. Pemurus Village has an area of \pm 645 Ha. The distance of Pemurus Village is $\pm 7 \mathrm{Km}$ from the District Capital, $\pm 53 \mathrm{Km}$ from the Regency Capital, namely Martapura (36.2\%) [5].

Family latrines are basic sanitation facilities to maintain environmental health in order to improve community health status. The problem of disease in the residential environment, especially in the disposal of feces, is one of the various health problems that need to be prioritized. Disposal of feces needs special attention because it is one of the waste materials that causes many problems in the health sector and as a medium for germs the effects of defecation are diarrhea, typhus, vomiting, dysentery, intestinal worms and itching. In addition, it can cause environmental pollution in water sources and foul odors and aesthetics. The greater the percentage of families who defecate indiscriminately, the higher the intensity of the disease threat $[6,7]$.

Knowledge is the result of knowing, and this occurs after people have sensed a certain object. Sensing occurs through the five human senses, namely the senses of sight hearing, smell, taste and touch, most of human knowledge is obtained through the eyes and ears. Someone's knowledge will have an impact on someone's actions or someone's behavior, someone with good knowledge will act according to what he knows, and is more likely to have better behavior when compared to someone with poor knowledge, in this case stop behavior. defecation. Therefore, there is a need for efforts to increase public knowledge about the dangers of open defecation in the river by local health workers such as counseling and health empowerment $[8,9]$.

Other than that, [10], states that there is a relationship between knowledge and the incidence of open defecation. People who are less knowledgeable have a greater chance of preferring to defecate in any place so that they are easily infected with various diseases such as diarrhea, typhoid diarrhea, vomiting, dysentery, intestinal worms and itching compared to those with good knowledge [10]. In line with [11] that open defecation behavior was found more in respondents with a low level of knowledge compared to respondents with a good level of knowledge [11].

Based on [12], there is a relationship between knowledge and people's habits of open defecation with the results of research in the field it is known that respondents' knowledge about PHBS and the benefits of latrines is still low, where some respondents still do not understand the benefits and objectives of defecating in latrines, so they use rivers and gardens to defecate. Besides, it is very difficult to change people's habits that have been entrenched, especially defecation behavior [12]. In line with [13], that there is a significant relationship between knowledge and in achieving the target of stopping open defecation [13]. 


\section{A. Objective}

Based on the description above, the purpose of this research is to determine the relationship between knowledge and open defecation behavior in Pemurus Village RT 003. Due to the importance of public knowledge about open defecation and stop defecation behavior, all people must apply it to avoid open defecation. from the threat of disease that can endanger the community itself.

\section{METHOD}

Field Learning Experience (PBL) 2 is a stage carried out by students after PBL 1 takes place by intervening. The stages of PBL 2 implementation are planning, implementation and proses, as well as monitoring and evaluation. Field learning experience 2 (PBL 2) is carried out online via Whatsapp. Participants in this activity amounted to 13 people who are members of the village community of RT 03.

The method used was quasy experimental using pretest and post-test. The number of samples is 13 people with the sampling technique is the total sampling collected in Pemurus Village RT. 03. In this activity, first, the distribution of pre-test questions to participants to find out how much knowledge participants have about the material that will be delivered by the instructor. After all participants finished answering the pre-test questions, it was continued with the main event, namely the provision of material. The material distributed was in the form of booklets, posters, and via Whatsapp text regarding healthy latrines in the Desa Pemurus RT whatsapp group. 03 whose material was given by a group of 13 so that residents could read.

Statistical analysis used univariate and bivariate analysis. Univariate analysis was conducted to obtain data about the frequency distribution, while bivariate analysis was an analysis that could be used to explain the relationship between two variables. In this analysis the statistical test used is the chi-square test with a $95 \%$ confidence level, because the variables studied are nominal in scale and using two groups of unpaired samples with the condition that the data must be normally distributed. If this assumption is not met then use the Fisher exact test. If the statistical test with $p$-value $<=0.05$, it is said that there is a relationship between the two variables by looking at the Odd Ratio (OR) value.

\section{RESULTS AND DISCUSSION}

Community service in the Field Learning Experience (PBL) 2 activity at RT 003 Village Pemurus Aluh - Aluh sub-district was held on November 27, 2020 to December 10, 2020. The activity was carried out through the Whatsapp Group and was attended by 13 residents of RT 003 Village Pemurus. One of the goals of holding this community service activity is to find out whether there are differences in knowledge after and before being given an intervention in the form of counseling. Before the statistical test is carried out, first the normality test is carried out on the pre-test and post-test results. The results of the data normality test can be seen in Table 1 below.

TABLE 1

NORMALITY TEST OF PRE-TEST AND POST-TEST DATA

\begin{tabular}{llll} 
Part & Frequency Distribution & Significant Value & Information \\
\hline & & & \\
Pre-Test Healthy Latrine Knowledge & 13 & 0.002 & Abnormal \\
Post-Test Healthy Latrine Knowledge & 13 & 0.001 & Abnormal \\
\hline
\end{tabular}

Based on the Table above, it is known that both the pre-test and post-test values of the respondents on the healthy latrine material are not normally distributed because the significant value is less than 0.05 (the Sig Pre test value $=0.002<0.05$ and the Sig Post test value $=$ 0.001 . < 0.05). So that the test is carried out with the Wilcoxon test, the results of which can be seen in Table 2 below.

TABLE 2

WILCOXON TEST (Z TEST)

\begin{tabular}{lll} 
Score & Pre-Test and Post-Test & Information \\
\hline$Z$ value (coefficient of difference) & $-2.154 \mathrm{~b}$ & There is a difference \\
Significant value $(p$-value) & .031 &
\end{tabular}


Wilcoxon test results against results pre-test and posttestabout knowledge of healthy latrines shows a Sig value of 0.031 , which means $<0.05$, namely Ho is rejected. This shows that there is a significant difference between the knowledge of the community in RT 003 Desa Pemurus when filling out the questionnaire before and after counseling.

Higher education has the obligation to carry out community service, in addition to carrying out education and research as mandated by Article 20 of Law no. 20 of 2003 concerning the National Education System. In line with this, Article 45 of Law no. 12 of 2012 concerning Higher Education emphasizes that community service is an activity of the academic community in practicing and cultivating science and technology to advance general welfare and the intellectual life of the nation [14].

Community service activities carried out in the Field Learning Experience (PBL) 2 at RT 003 Pemurus Village, Aluh-Aluh District were carried out with online counseling activities through Whatsapp Group regarding stopping open defecation and using healthy latrines. The results of statistical tests show that there is an increase in knowledge and there was a significant difference between the knowledge of the RT 003 Pemurus Village community at the time of filling out the questionnaire before and after the counseling. Health promotion in the form of counseling can provide learning to the community to help have knowledge or understanding, ability and willingness from the individual, family, group or community level to implement PHBS, one of which is using healthy latrines [15].

According to [16], knowledge is the result of someone knowing about objects through their senses. The resulting knowledge is influenced by the length of the intensity of attention and perception of the object. Each person's knowledge will be different depending on how each person perceives an object or something. Poor knowledge of the head of the family results in a lack of ability to use healthy latrines. This limited knowledge will have an adverse impact on health care for the head of the family and their family members $[16,17]$.

According to Lawrence Green's behavior theory in [16], knowledge is one of the predisposing factors that can determine a person's behavior. However, to realize the behavior of defecating using healthy latrines, knowledge is not enough. Other factors such as the availability of facilities in the form of adequate funds and environment, as well as support from the government, are other factors that can determine behavior change.

Based on research by [17, 18, 19], and [20], there is a relationship between knowledge and ownership of healthy latrines. The knowledge referred to in this study is everything that respondents know about the definition of a latrine, the requirements for a healthy latrine, the distance from which the feces can be stored to clean water, the benefits of a latrine. If someone has good knowledge about the use of latrines then the action to use the latrine will go well and having a healthy latrine is also good. However, if a person does not have good knowledge about the meaning, benefits, and types of latrines, the act of owning and using latrines will not work well $[17,18,19]$. This research is also in line with research conducted by [21]. Poor knowledge can affect the risk of disease transmission from good latrines from clean water facilities as well as from the equipment used as well as from environmental cleanliness [20, 21].

The results obtained that the risk of disease transmission in the community in the village is caused by: low public knowledge of the importance of using latrines. Respondents who lack of knowledge not having a healthy latrine can lead to a bad condition on the impact of public health and the environment, so that the community good knowledge can know it by following counseling, mass media, media social media and join women's associations because information can be obtained anywhere.

\section{CONCLUSION}

Community service in PBL 2 activity carried out to the community of RT 003 Pemurus Village, AluhAluh District aims to increase community knowledge and awareness about healthy latrines, manufacture of septic tanks, and be able to change people's behavior about healthy lifestyles. Based on the results of statistical tests, there is an increase in knowledge anda significant difference in people's knowledge when filling out the questionnaire before and after extension.

With the increase in knowledge in the community, it is hoped that it can be a trigger for the community to be able to apply defecation behavior using healthy latrines. To implement the behavior of defecating using healthy latrines, it is necessary to have a strong commitment from the community and the local village government to be able to provide healthy latrine facilities, both sourced from village funds or self-help funds collected by the community through the healthy latrine social gathering program.

\section{A. Limitations and Future Research}

The limitation of this service activity is that it is carried out online, so it cannot guarantee the success of interventions to change behavior. It would be better if this service activity was carried out by providing physical 
intervention in the form of training in making healthy latrines and forming healthy latrine cadres. In terms of data validity, because filling out the questionnaire was done online, the researcher cannot fully guarantee that the respondents who participated in this study were the head of the family, which could lead to information bias. It is hoped that further researchers can collect data directly from the community.

\section{REFERENCES}

[1] R. R. Anggoro, "Description of indiscriminate defecation behavior in the community of Jatimulyo Village, Bojonegoro Regency," Journal of Health Research, vol. 15, no. 2, pp. 129-134, 2017.

[2] S. W. Fitrianingsih, "Analysis of factors affecting open defecation behavior (BABS)," Journal of Sanitation and Environment, vol. 1, no. 2, pp. 51-57, 2019.

[3] L. Apriyanti, W. Bagoes, and L. Budi, "Factors influencing the use of family latrines in Jatibarang District, Brebes Regency," Indonesian Journal of Health Promotion, vol. 14, no. 1, pp. 1-14, 2019.

[4] Agency of Health Research and Development (Indonesia). (2013) Indonesia basic health research 2013. [Online]. Available: https://bit.ly/3qBOCwl

[5] M. K. Ikhwansyah. (2018) Banjar district health profile, 2018. [Online]. Available: https://bit.ly/3ya4lVH

[6] H. L, N. L. L, and T. M., "Factors influencing family behavior in using latrines in Air Pinang Village Settlement, East Simeulue District, Simeulue Regency 2018," Cehadum Health Journal, vol. 1, no. 3, pp. 15-27, 2019.

[7] Z. Szakaly and K. Peto, "Health behaviour, behaviour change and personalised diet: The concept of lifelong health," Journal of Advances in Health and Medical Sciences, vol. 4, no. 2, pp. 43-52, 2018. doi: https://doi.org/10.20474/jahms4.2.2

[8] N. S. Windy Febriani, Samino Samino, "Factors affecting changes in behavior of stopping open defecation (BABS): study on STBM Program in Sumbersari Village, Metro Selatan 2016.2016; 5 (3)." World Health Journal, vol. 5, no. 3, pp. 121-130, 2016.

[9] S. S. Alharbi, "Comparing australian my health record system implementation with global best practices with recommendations," Journal of Advances in Health and Medical Sciences, vol. 3, no. 2, pp. 63-74, 2017. doi: https://doi.org/10.20474/jahms3. 2.3
[10] F. P. Sari, "Implementation of community-based total sanitation program (STBM) with diarrhea in toddlers," Scientific Journal of Health, vol. 20, no. 1, pp. 10-15, 2021.

[11] A. Alfan, "Behavior of open defecation (BABS) in Kamal Village, Larangan District, Brebes Regency," Journal of Public Health (Undip), vol. 9, no. 2, pp. 166-174, 2021.

[12] Husna, "Analysis of knowledge and ownership of toilets with open defecation (BABS) habits (case study in Seumantok Village, Sampoinet District, Aceh Jaya Regency)," Aceh Public Health Magazine (MaKMA), vol. 1, no. 2, pp. 9-17, 2018.

[13] Muzaffar, "The relationship of public knowledge to attitudes in achieving the target of stopping open defecation in Mendale Village, Kebayakan District, Central Aceh Regency," Journal of Serambi Akademica, vol. 8, no. 8, pp. 1681-1687, 2020.

[14] Satriadi, Research and Community Service Handbook. Solok, Indonesia: Independent Intellectual Persons, 2020.

[15] A. S. Nasution, "PHBS education in household settings to improve healthy behavior," Abdidas Journal, vol. 1, no. 2, pp. 28-32, 2020.

[16] S. Notoatmodjo, Behavioral Health Sciences. Jakarta, Indonesia: Rineka Cipta, 2010.

[17] Y. Erlina, "Factors related to clean and healthy living behavior in household arrangements using healthy latrines in Dusun II RW. 04 Sukakarya Village, Sukakarya District, Bekasi Regency in 2016." Scientific Journal of Nursing, vol. 6, no. 1, pp. 1-12, 2016.

[18] O. Widyastutik, "Factors related to ownership of healthy latrines in Malikian Village, West Kalimantan Ikesmas," Journal of Public Health Sciences, vol. 13, no. 1, pp. 1-10, 2017.

[19] R. K. Sari, Ratnawati, and P. H. Livana, "Description of the factors that influence the coverage of healthy latrine ownership." Permas Scientific Journal: Stikes Kendal Scientific Journal, vol. 8, no. 1, pp. 56-62, 2018.

[20] L. Sumiarni, "Relationship of knowledge and economic status with healthy latrine ownership in Talang Segegah Village, Renah Pembarap District," Journal of Health and Applied Science STIKes Merangin, vol. 5, no. 2, pp. 51-60, 2019.

[21] R. Hayana and A. Ella, "Relationship of latrine ownership coverage in Kampung Baru Village, Pekanbaru City," Journal of Global Health, vol. 3, no. 1, pp. 9-17, 2020. 